\title{
Patient satisfaction as an element of healthcare quality - a single-center Polish survey
}

\author{
Adrian Pękacz ${ }^{1}$, Ewa Kądalska², Agnieszka Skoczylas², Tomasz Targowski ${ }^{2}$ \\ ${ }^{1}$ Deputy Administrative and Technical Affairs Director, National Institute of Geriatrics, Rheumatology and Rehabilitation, \\ Warsaw, Poland \\ ${ }^{2}$ Department of Geriatrics, National Institute of Geriatrics, Rheumatology and Rehabilitation, Warsaw, Poland
}

\begin{abstract}
Objectives: The aims of the study were to define the level of patient satisfaction with services provided by selected departments of the Institute, and to identify changes that should be introduced to the process of quality management in healthcare services.

Material and methods: A total of 455 patients from three departments of the National Institute of Geriatrics, Rheumatology and Rehabilitation in Warsaw, hospitalized between January 2016 and March 2018 were assessed retrospectively. Statistical analyses were conducted with the use of IBM SPSS Statistics 25 software.

Results: Patients at the Institute gave the highest rates to the courtesy and kindness of doctors and nurses (mean 4.77 and 4.73, respectively), the doctor's interest in a patient's well-being, and the nurses' dexterity in performing medical procedures (4.63 and 4.72, respectively) The lowest-rated were the quality of meals (mean 3.77 ) and the waiting time for hospital admission on an appointed day (mean 4.07). The study demonstrated statistically significant differences in evaluations made by female and male patients: women had worse opinions about maintenance of intimacy during medical procedures, whereas men gave lower ratings to the size of served meals. The level of satisfaction in all analyzed aspects increased with older age. However, a higher level of patient education correlated negatively with satisfaction from the waiting time for hospital admission on an appointed day, the ability to receive information about the disease and treatment process, cleanliness and accessibility of bathrooms and toilets, or the ability to easily move around the Institute.

Conclusions: Accessibility of medical services, as well as attitudes and competences of the medical staff, are all key factors in ensuring quality care. The conditions of a hospital stay also shape the patients' opinions in a significant way. Therefore, taking into account the patients' opinions should become an important goal in the process of improving healthcare quality.
\end{abstract}

Key words: hospital care, quality of healthcare, patients' satisfaction.

\section{Introduction}

Medical services offered by modern healthcare entities are individually evaluated by the recipients of those services; therefore, they require constant application of quality measurements, and the patient's level of satisfaction is a direct reflection of this quality [1-3]. Satisfaction is a result of meeting the client's expectations and may be defined as the state of being content with the received service, but it can also be described as the degree to which healthcare is accepted by the patient, considering his/her needs and expectations [2, 3].

Conducting a study of patient satisfaction is well justified by the fact that healthcare entities need to create competitive advantages on the medical services market. Moreover, such a study may become a valuable source of indications regarding the direction of further development or necessary organizational improvements [2, 3]. 
The National Institute of Geriatrics, Rheumatology and Rehabilitation in Warsaw is a scientific research institution and a healthcare entity that has been active on the medical services market for many years.

The current scope of the Institute's work includes participation in the healthcare system in the field of geriatrics and related disciplines, rheumatology, medical rehabilitation, orthopedics and musculoskeletal system traumatology, chronic diseases, medical conditions causing loss of independence, as well as in the field of fundamental sciences, gerontology, and public health. As a healthcare entity, the Institute was equipped with 223 beds during the study.

Intensifying efforts to improve the quality of provided services has become a priority in the current year. Studies regarding the identification of patients' needs, preferences, and satisfaction have been conducted in the Institute since the beginning of 2016. It was decided that research results will become a valuable component of diagnosing the current situation and will contribute to increased effectiveness in implementing a new mode of quality management in the provided services.

The aims of the study were to define the level of patient satisfaction with services provided by selected departments of the Institute, as well as to identify changes that should be introduced to the process of quality management in healthcare services.

\section{Material and methods}

This scientific work was designed to answer the following questions: What is the level of the patient's satisfaction with services provided in the Institute? How do patients rate the work of medical staff, including doctors and nurses? How do they rate being informed about the patient's rights, the opportunity to have a psychological consultation, hospital visiting hours, or the formality of giving consent to undergo tests and medical procedures? Furthermore, it has been recognized as important to investigate the opinions patients give about the conditions of their stay in the hospital, paying attention to the "hotel-like" services related to accommodation, alimentation, cleanliness, and accessibility of sanitary rooms.

Another subject of the researchers' interest was whether patients' opinions vary depending on their gender, age, level of education, place of residence, hospital ward on which they are staying, and if their evaluations change over three compared years, i.e. 2016-2018.

The voluntary and anonymous questionnaire surveys conducted in the period from January 2016 to March 2018 in patients hospitalized in the National Institute of Geriatrics, Rheumatology and Rehabilitation in Warsaw were evaluated retrospectively. The studies were carried out in three organizational units of the Institute: in the Department of Geriatrics, in the Department of Rheumatology and in the Department of the Systemic Diseases of Connective Tissue.

The studies involved adult participants who were able to fill in the survey's form independently (individuals not presenting advanced cognitive or functional deficits). The questionnaire was designed in the Institute in cooperation with the Commissioner for Patients' Rights. The form consisted of eight multiple-choice questions, one open-ended question, and demographic data.

At first, the respondents answered questions about the functioning of the Emergency Room, then they expressed their opinions about the work and attitude of doctors and nurses, the conditions of their stay at the hospital, and about being informed of their rights as patients. The respondents evaluated each component using a five-point estimation scale, in which numbers were assigned to specific descriptions characterizing the evaluated aspect (very bad -1 , bad -2 , satisfactory -3 , good -4 , very good -5 ).

At the end of the survey the participants were able to express their opinions in an open-ended question about fulfilment of their expectations and satisfaction from their stay and treatment.

\section{Statistical analysis}

In order to answer the questions asked by the authors of this study, statistical analyses were performed using IBM SPSS Statistics 25 software. Thanks to this statistic tool it was possible to conduct $U$ Mann-Whitney, Kruskal-Wallis, and Wilcoxon tests, as well as Spearman correlations analysis. The significance level defined for this study was $\alpha<0.05$.

\section{Results}

A total number of 455 patients took part in this study, including 133 patients (29.24\%) from the Department of Geriatrics, 178 patients (39.12\%) from the Department of Rheumatology, and 144 respondents (31.65\%) from the Department of the Systemic Diseases of Connective Tissue.

Table I presents the characteristics of patients in terms of their gender, age, level of education, and place of residence.

There were 314 women (69.01\%) and 141 men (30.99\%) in the examined group of patients. While most women were staying in the Department of Rheumatology $(n=145)$, which accounted for $31.87 \%$ of all participants, the lowest number of women were hospitalized in the Department of Geriatrics ( $n=66 ; 14.51 \%$ of all participants) (Table I). Most of the male patients, on the other hand, 
were treated in the Department of Geriatrics ( $n=67$; $14.73 \%$ of all respondents), whereas the lowest number of men were treated in the Department of Rheumatology ( $n=33 ; 7.25 \%$ of all respondents) (Table I).

The oldest participants were patients from the Department of Geriatrics (average age: 76.57 years) and the youngest were patients from the Department of Systemic Diseases of Connective Tissue (average age: 44.17 years). The average age of all patients who took part in the study was 58.41 years (Table I).

The largest group of respondents had higher (201; 44.18\% of all respondents) and secondary (193; $42.42 \%)$ education. A total of 364 participants were permanent residents of cities (80.0\%) and 91 lived in the country (20.0\%) (Table I).

The arithmetic means of grades from the questionnaires completed in individual clinics are compared in Table II.

The majority of patients rated the work of the Emergency Room as very good. The highest grades were awarded for courtesy of the medical staff. The lowest grades were given to waiting time for admission on the appointed day.

Other evaluated factors were work quality and attitude of doctors. Courtesy and kindness of doctors received the highest average grade -4.77 . The patients' opinions about the possibility to obtain information about the disease and treatment process from the doctors were slightly worse (average grade -4.43 ) (Table II).

In the aspect of nursing care, the respondents gave the highest grades to courtesy and kindness of nurses (arithmetic mean of all grades was 4.73). The dexterity of medical procedures performed by nurses was also rated very highly; the average grade for this parameter was 4.72. Availability of a nurse when needed was highly rated in the Department of Geriatrics - 4.85, while the average grade from all three departments was 4.07 (Table II).

When analyzing patient opinions about the conditions of their hospital stay (evaluation of patient rooms and alimentation), it should be recognized that the respondents evaluated the cleanliness and neatness of patient rooms as good (total average grade was 4.30). The cleanliness and accessibility of bathrooms and toilets was rated as moderately satisfactory (total arithmetic mean - 3.95) (Table II).

The quality of meals was also described as moderately satisfactory. The average grade for this parameter was 3.77. The average rating for meal size was 4.22 (Table II).

The ability to easily move around the Institute received an average grade of 4.50. The arithmetic mean

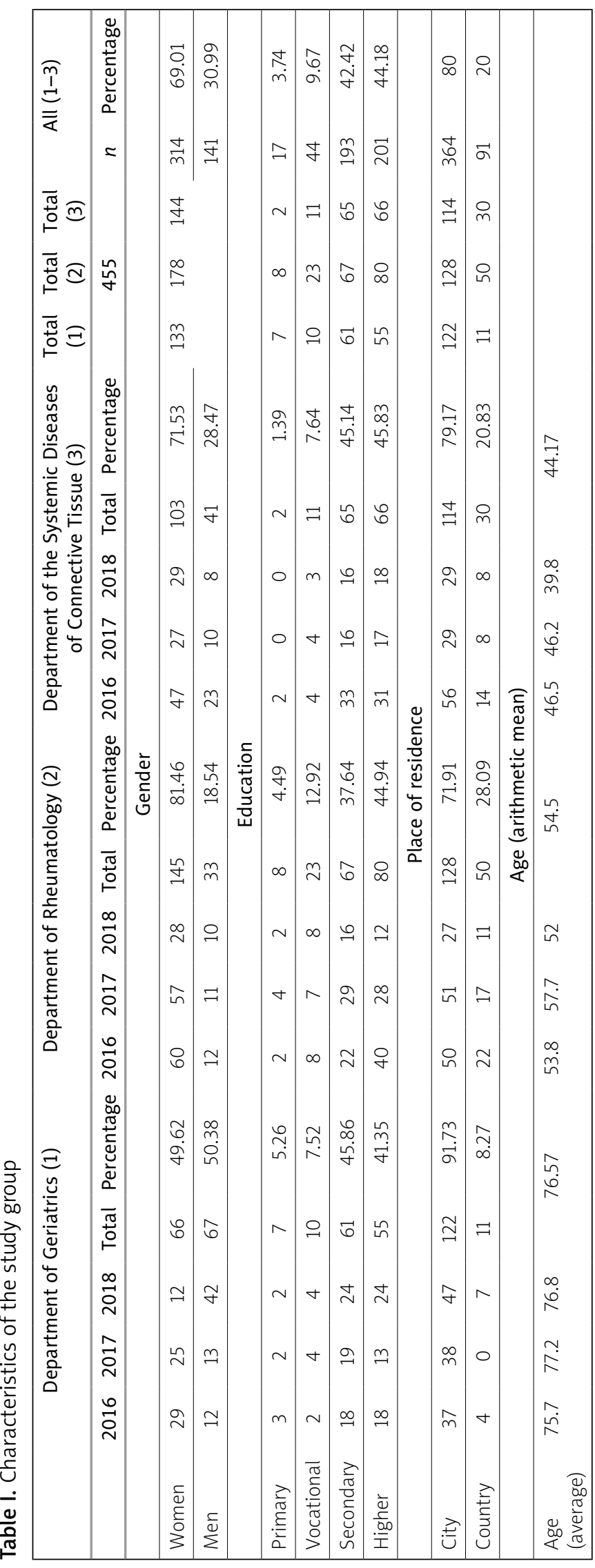


Table II. The arithmetic means of evaluated parameters in individual clinics in the period from January 2016 to March 2018

\begin{tabular}{|c|c|c|c|c|c|c|c|c|c|}
\hline \multirow[t]{3}{*}{ No. } & \multirow[t]{3}{*}{ Criteria/evaluation } & \multirow{2}{*}{\multicolumn{2}{|c|}{$\begin{array}{c}\text { Department } \\
\text { of Geriatrics }\end{array}$}} & \multirow{2}{*}{\multicolumn{2}{|c|}{$\begin{array}{c}\text { Department } \\
\text { of Rheumatology }\end{array}$}} & \multicolumn{4}{|c|}{$\begin{array}{l}\text { Department of Systemic Diseases } \\
\text { of Connective Tissue }\end{array}$} \\
\hline & & & & & & \multicolumn{2}{|c|}{ Total } & \multicolumn{2}{|r|}{ All } \\
\hline & & $\begin{array}{c}\text { All } \\
\text { examined } \\
(n)\end{array}$ & $\begin{array}{l}\text { Arithmetic } \\
\text { mean }\end{array}$ & $\begin{array}{c}\text { All } \\
\text { examined } \\
(n)\end{array}$ & $\begin{array}{l}\text { Arithmetic } \\
\text { mean }\end{array}$ & $\begin{array}{c}\text { All } \\
\text { examined } \\
(n)\end{array}$ & $\begin{array}{l}\text { Arithmetic } \\
\text { mean }\end{array}$ & $n$ & $\begin{array}{l}\text { Arithmetic } \\
\text { mean }\end{array}$ \\
\hline 1 & $\begin{array}{l}\text { Qualification and } \\
\text { making an appoint- } \\
\text { ment for treatment }\end{array}$ & 129 & 4.64 & 178 & 440 & 144 & 3.93 & 451 & 4.33 \\
\hline 2 & $\begin{array}{l}\text { Admission waiting } \\
\text { time on the appoint- } \\
\text { ed day }\end{array}$ & 131 & 4.24 & 178 & 4.26 & 144 & 3.71 & 453 & 4.07 \\
\hline 3 & $\begin{array}{l}\text { Courtesy of the med- } \\
\text { ical staff in the ER }\end{array}$ & 133 & 4.80 & 179 & 4.67 & 143 & 4.40 & 455 & 4.62 \\
\hline 4 & $\begin{array}{l}\text { Courtesy and kind- } \\
\text { ness of doctors }\end{array}$ & 133 & 4.92 & 176 & 4.84 & 144 & 4.55 & 453 & 4.77 \\
\hline 5 & $\begin{array}{l}\text { Interest in the pa- } \\
\text { tient's well-being }\end{array}$ & 132 & 4.81 & 177 & 4.76 & 144 & 4.33 & 453 & 4.63 \\
\hline 6 & $\begin{array}{l}\text { Providing informa- } \\
\text { tion about methods } \\
\text { of treatment and } \\
\text { examination }\end{array}$ & 132 & 4.69 & 177 & 4.64 & 139 & 4.10 & 448 & 4.48 \\
\hline 7 & $\begin{array}{l}\text { Ability to receive infor- } \\
\text { mation regarding the } \\
\text { course of the disease } \\
\text { and treatment plan }\end{array}$ & 133 & 4.63 & 177 & 4.64 & 144 & 4.03 & 454 & 4.43 \\
\hline 8 & $\begin{array}{l}\text { Courtesy and kind- } \\
\text { ness of nurses }\end{array}$ & 132 & 4.90 & 178 & 4.78 & 144 & 4.49 & 454 & 4.73 \\
\hline 9 & $\begin{array}{l}\text { Explanations regard- } \\
\text { ing the preparation } \\
\text { for tests and proce- } \\
\text { dures }\end{array}$ & 133 & 4.75 & 178 & 4.65 & 144 & 4.15 & 455 & 4.51 \\
\hline 10 & $\begin{array}{l}\text { Maintaining intima- } \\
\text { cy when providing } \\
\text { nursing care }\end{array}$ & 132 & 4.77 & 175 & 4.66 & 143 & 4.18 & 450 & 4.53 \\
\hline 11 & $\begin{array}{l}\text { Dexterity of perform- } \\
\text { ing medical proce- } \\
\text { dures by nurses }\end{array}$ & 132 & 4.86 & 178 & 4.82 & 144 & 4.50 & 454 & 4.72 \\
\hline 12 & $\begin{array}{l}\text { Availability of a nurse } \\
\text { if there is a need }\end{array}$ & 133 & 4.85 & 177 & 4.76 & 142 & 4.07 & 452 & 4.56 \\
\hline 13 & $\begin{array}{l}\text { Cleanliness and } \\
\text { neatness in the room }\end{array}$ & 132 & 4.86 & 177 & 4.73 & 144 & 3.30 & 453 & 4.30 \\
\hline 14 & $\begin{array}{l}\text { Cleanliness and } \\
\text { accessibility of bath- } \\
\text { rooms and toilets }\end{array}$ & 132 & 4.54 & 177 & 4.62 & 142 & 2.68 & 451 & 3.95 \\
\hline 15 & $\begin{array}{l}\text { The quality of } \\
\text { offered meals }\end{array}$ & 132 & 4.11 & 177 & 3.78 & 144 & 3.41 & 453 & 3.77 \\
\hline 16 & $\begin{array}{l}\text { The size of offered } \\
\text { meals }\end{array}$ & 132 & 4.48 & 176 & 4.23 & 144 & 3.96 & 452 & 4.22 \\
\hline 17 & $\begin{array}{l}\text { The ability to easily } \\
\text { move around the } \\
\text { Institute }\end{array}$ & 130 & 4.53 & 178 & 4.66 & 144 & 429 & 452 & 4.50 \\
\hline
\end{tabular}


Table III. Comparison of women and men in terms of the level of satisfaction with services provided in the Institute

\begin{tabular}{|c|c|c|c|c|}
\hline Provided services & & $\begin{array}{c}\text { Men } \\
(n=111)\end{array}$ & $\begin{array}{l}\text { Women } \\
(n=339)\end{array}$ & $p$ \\
\hline \multirow{3}{*}{$\begin{array}{l}\text { Emergency Room } \\
\text { work }\end{array}$} & Qualification and making an appointment for hospital treatment & 235.55 & 222.21 & 0.297 \\
\hline & Admission waiting time on the appointed day & 216.07 & 229.94 & 0.297 \\
\hline & Courtesy of the medical staff in the Emergency Room & 233.25 & 224.97 & 0.471 \\
\hline \multirow[t]{4}{*}{ The work of doctors } & Courtesy and kindness of doctors & 221.19 & 228.91 & 0.394 \\
\hline & Interest in the patient's well-being & 228.63 & 225.80 & 0.796 \\
\hline & Providing information regarding methods of treatment and tests & 232.02 & 224.70 & 0.531 \\
\hline & $\begin{array}{l}\text { Opportunity to obtain information about the disease and course } \\
\text { of treatment }\end{array}$ & 227.88 & 226.71 & 0.923 \\
\hline \multirow{5}{*}{$\begin{array}{l}\text { The work of nursing } \\
\text { staff }\end{array}$} & Courtesy and kindness of nurses & 233.52 & 224.88 & 0.419 \\
\hline & Explanations on how to prepare for examination/surgery & 238.22 & 223.36 & 0.217 \\
\hline & Maintaining intimacy when performing medical procedures & 245.74 & 218.19 & 0.017 \\
\hline & Dexterity in performing medical procedures & 240.20 & 222.71 & 0.082 \\
\hline & Availability of the nurse when needed & 234.44 & 223.25 & 0.303 \\
\hline \multirow[t]{6}{*}{ Stay in the hospital } & Cleanliness and neatness in the room & 237.78 & 222.78 & 0.208 \\
\hline & Cleanliness and accessibility of bathrooms and toilets & 221.67 & 226.77 & 0.695 \\
\hline & Courtesy of the assisting personnel & 150.31 & 153.76 & 0.720 \\
\hline & Quality of offered meals & 230.26 & 225.26 & 0.713 \\
\hline & Size of offered meals & 203.23 & 233.52 & 0.022 \\
\hline & The ability to easily move around the Institute & 213.51 & 228.82 & 0.207 \\
\hline
\end{tabular}

U Mann-Whitney test, medium rank, $p<0.05$ is significant.

of grades awarded to this parameter by patients hospitalized in the Department of Geriatrics amounted to 4.53 (Table II).

The overall average evaluation of medical services offered in the Institute, expressed by the respondents in numeric scale, was 4.42, or very good (Table II).

All participants of the study were also asked to share their opinion on getting acquainted with patients' rights, being informed about the opportunity of a psychological consultation, about hospital visiting rules and about the formality of giving consent for undergoing tests and medical procedures. A vast majority of patients confirmed they had been informed about patients' rights ( $n=372,81.94 \%)$ and about unrestricted visiting hours in the hospital ( $n=451,99.12 \%)$. A total of 411 patients ( $90.53 \%$ of all respondents) were informed about the formality of giving consent to undergo tests and medical procedures. Providing information about possible psychological consultations was seen as slightly worse -209 respondents, who constituted $46.06 \%$ of all patients, were aware of this opportunity (Table II).

Using statistical tests in the first place allowed us to compare the level of satisfaction among women and men. The analysis proved, on a statistically significant level, that women have a worse opinion than men regarding maintenance of intimacy during medical procedures, whereas men give lower ratings for the size of served meals. No other statistically significant differences were observed in the remaining evaluated aspects. All results are presented in Table III.

Next, differences in the level of satisfaction between respondents who live in cities and in the country were examined. The analysis showed statistically significant differences in three of all the evaluated aspects regarding the hospital stay - patients who live in the country gave higher grades for the quality of meals offered in the hospital and the ability to easily move around the Institute. Other differences turned out to be statistically insignificant. Detailed results are presented in Table IV.

The analysis of correlations between the level of satisfaction and respondents' age and level of education was conducted afterwards. The analysis showed a statistically significant positive correlation between older age and higher level of satisfaction in all measured indicators (Table V). In terms of the level of education, it presented a statistically significant negative correlation with the evaluation of waiting time for admission to the ward on the appointed day, with the ability to receive 
Table IV. Comparison of satisfaction levels with provided services in relation to place of living

\begin{tabular}{|c|c|c|c|c|}
\hline \multicolumn{2}{|c|}{ Provided services } & \multirow{2}{*}{$\begin{array}{c}\text { Country } \\
(n=90)\end{array}$} & \multirow{2}{*}{$\begin{array}{c}\text { City } \\
(n=359) \\
222.80\end{array}$} & \multirow{2}{*}{$\begin{array}{c}p \\
0.425\end{array}$} \\
\hline Emergency & Qualification and making an appointment for hospital treatment & & & \\
\hline & Admission waiting time on the appointed day & 238.08 & 222.99 & 0.293 \\
\hline & Courtesy of the medical staff in the Emergency Room & 234.51 & 224.51 & 0.419 \\
\hline \multirow{4}{*}{$\begin{array}{l}\text { The work } \\
\text { of doctors }\end{array}$} & Courtesy and kindness of doctors & 234.32 & 224.58 & 0.322 \\
\hline & Interest in the patient's well-being & 231.06 & 224.74 & 0.591 \\
\hline & Providing information regarding methods of treatment and tests & 236.11 & 223.48 & 0.316 \\
\hline & Opportunity to obtain information about the disease and course of treatment & 238.73 & 223.46 & 0.243 \\
\hline \multirow{5}{*}{$\begin{array}{l}\text { The work } \\
\text { of nursing } \\
\text { staff }\end{array}$} & Courtesy and kindness of nurses & 227.97 & 226.13 & 0.873 \\
\hline & Explanations on how to prepare for examination/surgery & 235.98 & 224.14 & 0.361 \\
\hline & Maintaining intimacy when performing medical procedures & 221.50 & 225.25 & 0.762 \\
\hline & Dexterity in performing medical procedures & 226.11 & 226.60 & 0.964 \\
\hline & Availability of the nurse when needed & 232.30 & 223.80 & 0.468 \\
\hline \multirow{6}{*}{$\begin{array}{l}\text { Stay in the } \\
\text { hospital }\end{array}$} & Cleanliness and neatness in the room & 235.10 & 223.73 & 0.377 \\
\hline & Cleanliness and accessibility of bathrooms and toilets & 236.79 & 222.04 & 0.294 \\
\hline & Courtesy of the assisting personnel & 154.30 & 152.02 & 0.816 \\
\hline & Quality of offered meals & 257.83 & 218.07 & 0.007 \\
\hline & Size of offered meals & 248.53 & 219.74 & 0.044 \\
\hline & The ability to easily move around the Institute & 249.52 & 218.21 & 0.017 \\
\hline
\end{tabular}

U Mann-Whitney test, medium rank, $p<0.05$ is significant.

information about the disease and treatment process, with the cleanliness and accessibility of bathrooms and toilets, and with the ability to easily move around the Institute (Table V).

Then, satisfaction levels of patients hospitalized in different clinics of the Institute were compared. The analysis proved statistically significant differences in every comparison. In terms of the quality and size of served meals, differences applied to all departments, among which the highest grades were awarded by patients from the Department of Geriatrics, followed by the Department of Rheumatology, and the lowest grades were given by patients hospitalized in the Department of Systemic Diseases of Connective Tissue. Considering all other evaluated aspects, a significantly lower level of satisfaction was observed in patients treated in the Department of Systemic Diseases of Connective Tissue, when compared to the level of satisfaction among patients staying in two other clinics. Detailed results are presented in Table VI.

The next part of the analysis compared satisfaction with the work of doctors and nurses. Due to a different pattern of evaluation in these two groups, average grades from all evaluated aspects were compared. In the evaluation of doctors' work the level of satisfaction received the following parameters ( $M$ : 4.58; SD: 0.72), whereas in evaluating the work of the nursing staff it was ( $M$ : 4.64; SD: 0.55). An analysis with the use of Wilcoxon's test showed an absence of any statistically significant difference between these two groups $(p=0.226)$.

\section{Discussion}

Quality management in healthcare includes a number of aspects, among which patient satisfaction itself may be a groundwork for initiating processes aimed at improving quality. Consumer-oriented medical services and meeting patients' expectations speak clearly on behalf of the need to systematically study and analyze patient satisfaction. Such an approach allows us to recognize specific opinions of the patients and to identify the reasons behind the lack of satisfaction with received services. This makes introduction of corrective actions possible [4, 5].

Keeping in mind that the client acts as a "storage medium for information about the organization", it should be realized that neglecting appropriate care for specific needs of patients poses the real threat of losing not only the client but also the reputability of a healthcare entity on the medical services market [4].

The presented study proves that patient's satisfaction has various reference points and includes a number 
Table V. Correlation between age and level of education with the level of satisfaction with services provided at the Institute

\begin{tabular}{|c|c|c|c|c|c|}
\hline \multicolumn{2}{|c|}{ Provided services } & \multicolumn{2}{|c|}{ Age } & \multicolumn{2}{|c|}{ Education } \\
\hline & & $r$ & $p$ & $r$ & $p$ \\
\hline \multirow{3}{*}{$\begin{array}{l}\text { Emergency } \\
\text { Room work }\end{array}$} & Qualification and making an appointment for hospital treatment & 0.25 & $<0.001$ & -0.07 & 0.117 \\
\hline & Admission waiting time on the appointed day & 0.19 & 0.001 & -0.09 & 0.045 \\
\hline & Courtesy of the medical staff in the Emergency Room & 0.23 & $<0.001$ & -0.07 & 0.113 \\
\hline \multirow{4}{*}{$\begin{array}{l}\text { The work } \\
\text { of doctors }\end{array}$} & Courtesy and kindness of doctors & 0.19 & $<0.001$ & -0.05 & 0.262 \\
\hline & Interest in the patient's well-being & 0.20 & $<0.001$ & -0.11 & 0.023 \\
\hline & Providing information regarding methods of treatment and tests & 0.16 & 0.004 & -0.08 & 0.080 \\
\hline & $\begin{array}{l}\text { Opportunity to obtain information about the disease and course } \\
\text { of treatment }\end{array}$ & 0.15 & 0.007 & -0.10 & 0.042 \\
\hline \multirow{5}{*}{$\begin{array}{l}\text { The work } \\
\text { of nursing } \\
\text { staff }\end{array}$} & Courtesy and kindness of nurses & 0.19 & 0.001 & -0.09 & 0.066 \\
\hline & Explanations on how to prepare for examination/surgery & 0.26 & $<0.001$ & -0.07 & 0.122 \\
\hline & Maintaining intimacy when performing medical procedures & 0.26 & $<0.001$ & -0.09 & 0.068 \\
\hline & Dexterity in performing medical procedures & 0.22 & $<0.001$ & -0.05 & 0.275 \\
\hline & Availability of the nurse when needed & 0.27 & $<0.001$ & -0.09 & 0.070 \\
\hline \multirow{6}{*}{$\begin{array}{l}\text { Stay in the } \\
\text { hospital }\end{array}$} & Cleanliness and neatness in the room & 0.35 & $<0.001$ & -0.07 & 0.133 \\
\hline & Cleanliness and accessibility of bathrooms and toilets & 0.41 & $<0.001$ & -0.12 & 0.009 \\
\hline & Courtesy of the assisting personnel & 0.20 & 0.003 & -0.08 & 0.155 \\
\hline & Quality of offered meals & 0.26 & $<0.001$ & -0.11 & 0.025 \\
\hline & Size of offered meals & 0.27 & $<0.001$ & -0.09 & 0.053 \\
\hline & The ability to easily move around the Institute & 0.11 & 0.050 & -0.13 & 0.006 \\
\hline
\end{tabular}

Spearman correlation test, $p<0.05$ is significant.

of opinions, the fulfilment of which requires constant analyses, as well as systematically and precisely improving actions, which constitute the system of quality management in a healthcare entity.

A process of profound changes in the management system has been planned in the National Institute of Geriatrics, Rheumatology and Rehabilitation in Warsaw. This process is expected to last a few years, and its purpose is to adjust to current trends, international norms, and modern methods of optimizing and improving healthcare management systems (Lean HealthCare methodology).

Although the questionnaires employed in the study did not seem fully adapted to the concept of profound qualitative and quantitative analysis, it was decided that they would be used because authors of this survey recognized these questionnaires contain valuable opinions and tips from clients/patients of the Institute.

The conducted analyses prove that the majority of patients are very satisfied with the courtesy and kindness of doctors and nurses. Moreover, doctors are praised for their interest in the patient's well-being and providing information about the disease and course of treatment.
However, they received lower grades for providing information regarding treatment options and test methods.

The nurses were highly rated for their courtesy and kindness, as well as for dexterity in performing medical procedures, availability when needed, and maintaining intimacy when offering nursing care to patients. They received slightly lower grades for providing explanations regarding preparation for examinations and surgeries.

The conditions of hospital stay, cleanliness, and neatness in patient rooms received the highest grades from patients hospitalized in the Department of Geriatrics. Cleanliness and accessibility of bathrooms and toilets was evaluated as worse than cleanliness of patient rooms in all clinics included in the study. The lowest grades were allocated to the quality and size of meals offered in the hospital. The respondents agreed that moving around the Institute posed some difficulties.

Functioning of the Emergency Room received different ratings. Waiting time for admission on the appointed day received the lowest grades, whereas qualification for making an appointment for treatment was better perceived and the courtesy of medical staff received the highest grades. The Emergency Room's work was more 
Table VI. Comparison of levels of satisfaction with medical services provided at the Institute between patients from different departments of the Institute

\begin{tabular}{|c|c|c|c|c|}
\hline \multicolumn{2}{|c|}{ Provided services } & \multirow{2}{*}{$\begin{array}{l}\text { Department } \\
\text { of Geriatrics } \\
(n=132) \\
263.96^{\mathrm{a}}\end{array}$} & \multirow{2}{*}{$\begin{array}{c}\begin{array}{c}\text { Department } \\
\text { of Rheumatology } \\
(n=178)\end{array} \\
241.69^{b}\end{array}$} & \multirow{2}{*}{ 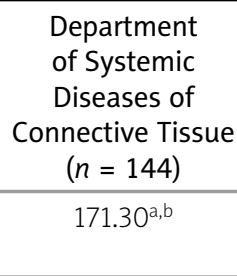 } \\
\hline $\begin{array}{l}\text { Emergency } \\
\text { Room work }\end{array}$ & $\begin{array}{l}\text { Qualification and making an appointment for hospital } \\
\text { treatment }\end{array}$ & & & \\
\hline & Admission waiting time on the appointed day & $248.37^{a}$ & $246.71^{b}$ & $181.77^{a, b}$ \\
\hline & Courtesy of the medical staff in the Emergency Room & $243.05^{a}$ & $240.58^{b}$ & $195.28^{a, b}$ \\
\hline \multirow{4}{*}{$\begin{array}{l}\text { The work } \\
\text { of doctors }\end{array}$} & Courtesy and kindness of doctors & $246.69^{a}$ & $238.04^{b}$ & $195.39^{a, b}$ \\
\hline & Interest in the patient's well-being & $246.07^{a}$ & $245.63^{b}$ & $185.18^{a, b}$ \\
\hline & $\begin{array}{l}\text { Providing information regarding methods of treatment } \\
\text { and tests }\end{array}$ & $245.69^{a}$ & $247.76^{b}$ & $182.91^{\mathrm{a}, \mathrm{b}}$ \\
\hline & $\begin{array}{l}\text { Opportunity to obtain information about the disease } \\
\text { and course of treatment }\end{array}$ & $246.46^{\mathrm{a}}$ & $252.14^{b}$ & $178.25^{a, b}$ \\
\hline \multirow{5}{*}{$\begin{array}{l}\text { The work } \\
\text { of nursing } \\
\text { staff }\end{array}$} & Courtesy and kindness of nurses & $252.59^{\mathrm{a}}$ & $240.85^{b}$ & $186.60^{a, b}$ \\
\hline & Explanations on how to prepare for examination/surgery & $261.24^{\mathrm{a}}$ & $242.51^{b}$ & $176.67^{a, b}$ \\
\hline & $\begin{array}{l}\text { Maintaining intimacy when performing medical proce- } \\
\text { dures }\end{array}$ & $252.98^{\mathrm{a}}$ & $242.59^{b}$ & $177.84^{a, b}$ \\
\hline & Dexterity in performing medical procedures & $246.49^{a}$ & $238.28^{b}$ & $195.32^{a, b}$ \\
\hline & Availability of the nurse when needed & $254.75^{a}$ & $243.45^{b}$ & $177.52^{\mathrm{a}, \mathrm{b}}$ \\
\hline \multirow{6}{*}{$\begin{array}{l}\text { Stay in the } \\
\text { hospital }\end{array}$} & Cleanliness and neatness in the room & $281.14^{a}$ & $254.64^{b}$ & $142.20^{a, b}$ \\
\hline & Cleanliness and accessibility of bathrooms and toilets & $278.55^{a}$ & $287.70^{\mathrm{b}}$ & $99.03^{a, b}$ \\
\hline & Courtesy of the assisting personnel & $171.35^{\mathrm{a}}$ & $155.46^{\mathrm{b}}$ & $96.12^{a, b}$ \\
\hline & Quality of offered meals & $270.18^{\mathrm{a}}$ & $235.58^{a}$ & $175.60^{\mathrm{a}}$ \\
\hline & Size of offered meals & $273.70^{\mathrm{a}}$ & $237.52^{\mathrm{a}}$ & $168.52^{\mathrm{a}}$ \\
\hline & The ability to easily move around the Institute & $232.33^{\mathrm{a}}$ & $246.09^{b}$ & $192.56^{a, b}$ \\
\hline
\end{tabular}

${ }^{a}$ Kruskal-Wallis test, ${ }^{b}$ post hoc analysis with Dunn-Bonferroni correction, medium rank, $p<0.05$ is significant.

valued by patients from the Department of Geriatrics when compared to all other departments.

A vast majority of respondents confirmed they had been informed of patients' rights and that there were almost no restrictions to the access of family/relatives to patients and visiting opportunities. Providing information about the possibility to give consent for undergoing tests and medical procedures was positively evaluated.

The study demonstrated statistically significant differences in evaluations made by female and male patients, people who permanently live in the countryside and in cities, as well as in terms of the patients' level of education. A surprising result is the statistically significant positive correlation between the age and all measured indicators of satisfaction, which means that the older the patients were, the higher their level of satisfaction. Furthermore, it is interesting that for each analyzed parameter the level of satisfaction was highest in 2017.
The Department of Geriatrics possesses advanced equipment and medical apparatus. It offers the fastest admission of patients to the Emergency Room (which can be explained by the need for fast laboratory diagnostics in elderly patients). The Department of Geriatrics carries out a Comprehensive Geriatric Assessment of patients according to the geriatric care guidelines (Official Position of the Polish Society of Gerontology developed by experts from the Ministry of Health Board for Gerontology in 2013) [6]. According to these standards the care for a geriatric patient is provided by an interdisciplinary team including i.a. a doctor, nurses, a physiotherapist, a psychologist, and a healthcare assistant. This team undertakes comprehensive diagnostic, therapeutic, preventive, educational, and protective actions, at the same time providing information resulting from the treatment plan and supporting the family members and other caregivers. This close and frequent contact between the interdisciplinary team mem- 
bers, the patient, and his/her family or relatives may have important influence on the patient's satisfaction with the provided care and its high rating.

When analyzing respondents' answers from the years 2016-2018 it was noted that, despite general satisfaction with received medical services, there was a trend for gradual deterioration of opinions expressed by patients. This, in particular, encourages us to reflect on the need to introduce quality changes.

The results obtained in this study may be related to similar studies mentioned in the literature.

The study conducted by Adamus et al. [7] describes surveys conducted in 2012, which involved 36 hospitalized patients from three hospitals in the Lesser Poland voivodship. This study used the method of a questionnaire interview with the help of multiple criteria decision support - AHP. The participants most often indicated the significance of care provided by doctors and nurses and then also emphasized the importance of services availability, including those provided by doctors and nurses, and communication between medical staff and patients. The greatest meaning was given to doctor's availability and trust in doctor, as well as to the availability of nurses both during the day and at night. The courtesy and empathy of medical staff was less significant to respondents. Examination of the patient before a medical procedure/surgery on surgical wards turned out to be the most important in evaluation of the stay on the ward and evaluation of the procedure/ surgery itself. Waiting time for admission to the hospital was recognized as the most important component of the medical service availability [7].

Studies conducted in 2013 by Leźnicka et al. [5] in eight stationary healthcare institutions in the KuyavianPomeranian Voivodship involved a total of 2281 patients. Five of the hospitals included in this survey are general hospitals (1326 questionnaires were collected), two are psychiatric hospitals (754 forms), and one is a pediatric hospital (201 forms). This study used the PASAT model designed by the Centre for Monitoring Quality in Healthcare [5]. The respondents gave the highest ratings to the courtesy of nursing staff, accuracy of procedures performed by nurses, and their availability both during the day and at night. The highest grades among doctors were awarded for courtesy and speaking in a way that is understandable to patients. The most important aspects of the hospital stay, beginning from the most significant, were: quality of meals, accessibility of bathrooms for patients, and cleanliness of hospital rooms. Providing insufficient information about patients' rights, side effects of medications, daily schedule, or the rules that apply on a specific ward are problems that were observed during this survey.
A study conducted by Bowling et al. [8] in a British facility in Southampton among 883 patients from 21 hospitals and 22 family practices proved the ability of the healthcare system (the National Health Service NHS) to meet patients' expectations in terms of clinical effects, as well as regular human needs and emotions, which are the most important for those respondents. Generally speaking, it turned out that elderly people were satisfied with the medical services they were receiving. In such a context, this study debunks dominant stereotypes of older age: elderly patients are more satisfied with healthcare not because of their lower expectations; their expectations are in fact higher, but these patients believe their expectations are met [8].

Another interesting scientific work presents a comparison of our study results to the surveys conducted in 2015-2016 in a Norwegian institution (Faculty of Health and Welfare, Ostfold University College, Halden), in which the perception of healthcare quality among patients from an "old" (253) and contemporarily arranged and equipped hospital (324) was different. These results show that advanced technologies allow for increased patient satisfaction with care in terms of evaluating conditions of the hospital environment in which they are staying. However, this has no influence on how direct healthcare quality provided by hospital staff is perceived by patients. The authors of this study conclude that we should find application for new technologies as a valuable method of supporting medical personnel in targeting individual care needs of patients [9].

In the light of comparative studies, although such studies use different methods and research tools, the quality of a particular service is constantly perceived through the patient's satisfaction level and fulfilment of his or her expectations in basic factors of reference: accessibility, communication, care, and conditions of stay. The presented research and literature analysis both seem to confirm the validity of some conclusions formed in our study.

In conclusion, it is worth emphasizing that responding to patients' expectations is the foundation for undertaking any quality-improving actions by modern healthcare entities.

The results of conducted surveys confirm that availability of medical services as well as attitudes and competences of medical staff are crucial not only in ensuring quality of services but also in shaping the healthcare entity's profile and securing its presence and position on the medical services market [10-13].

Patient satisfaction is a deeply emotional and subjective evaluation by a consumer of medical services. Considering its immaterial, unstable, and variable character, patient's satisfaction requires constant involve- 
ment in maintaining clients and attracting new ones, as well as challenging the competition in quality management $[2,10,14]$.

In order to face these challenges, it may be helpful to introduce a management system aimed at assimilation of current international quality norms and implementation of advanced methods for optimizing and improving management systems in healthcare.

\section{Limitations of this study}

The authors recognize certain limitations of this retrospective study. The study was not representative for the overall population of hospitalized patients in Poland. In our opinion, the research tool we used in this survey requires improvement. The instruction on how to fill in the questionnaire should be clearer and put greater emphasis on the aim of the study to improve the quality of services offered at the National Institute of Geriatrics, Rheumatology and Rehabilitation. The questionnaire should contain more objectified criteria for evaluation of provided services, according to the ISO 9001:2015 norm (in:) PN-EN ISO 9001:2015, Quality management systems. Requirements. Participation of an internal and external "client", a representative for the whole institution, would be advisable. The choice of questions and their significance should be closely analyzed in terms of the study's aim. Applying rank methods and a more adequate scaling of multiple-choice answers should be considered. Also, the questionnaire should be given to patients personally, preferably by a third person who does not work in a particular clinic/department, instead of placing the forms in a widely-available location, as was done in this study. These actions would certainly increase the percentage of completed questionnaires and provide the research team with more interesting data for analysis.

\section{Conclusions}

Based on the conducted studies, the following conclusions were formed:

1. The patients' satisfaction with medical services provided by the National Institute of Geriatrics, Rheumatology and Rehabilitation in Warsaw is generally high. Overall average evaluation expressed by respondents in numeric scale was 4.42, which is very good.

2. Accessibility of medical services, as well as attitudes and competences of the medical staff, are all key factors in ensuring quality care.

3. The conditions of a hospital stay also shape the patients' opinions in a significant way. Therefore, taking into account the patients' opinions in this regard should become an important goal in the process of improving healthcare quality.

\section{Acknowledgements}

The authors thank Mrs. Katarzyna Humięcka and Mrs. Elżbieta Mądra for their help in carrying out the research.

The authors declare no conflict of interest.

\section{References}

1. Dobska M, Dobski P. Systemy zarządzania jakością w podmiotach leczniczych. Wolters Kluwer, Warszawa 2016.

2. Trela A. Zarządzanie jakością w działalności leczniczej. Wydawnictwo Wiedza i Praktyka Sp. z o.o., Warszawa 2016.

3. Plentara R, Knyszyńska A, Bażydło M, et al. Satysfakcja pacjentów podstawowej opieki zdrowotnej z opieki medycznej i psychospołecznej. Pom J Life Sci 2015; 61: 335-340.

4. Małecka B, Marcinkowski JT. Satysfakcja pacjenta czynnikiem kształtującym współczesny rynek usług medycznych. Probl Hig Epidemiol 2007; 88: 17-19.

5. Leźnicka M, Warunek A, Hartwich E, et al. Ocena satysfakcji pacjenta z usług świadczonych w stacjonarnej opiece zdrowotnej w województwie kujawsko-pomorskim. Hygeia Public Health 2014; 49: 787-792.

6. Standardy postępowania w opiece geriatrycznej. Stanowisko Polskiego Towarzystwa Gerontologicznego opracowane przez ekspertów Zespołu ds. Gerontologii przy Ministrze Zdrowia. Gerontol Pol 2013; 21: 233-247.

7. Adamus W, Adamus T. Ocena szpitali z perspektywy pacjentów. Zdrowie Publiczne i Zarządzanie 2012; 10: 251-265.

8. Bowling A, Rowe G, McKee M. Patients 'experiences of their healthcare in relation to their expectations and satisfaction: a population survey. JR Soc Med 2013; 106: 143-149.

9. Grøndahl VA, Kirchhoff JW, Andersen KL, et al. Health care quality form patients 'perspective: a comparative study between an old and a new, high-tech hospital. J Multidiscip Healthc 2018; 11: 591-600.

10. Rudawska I. Opieka zdrowotna aspekty rynkowe i marketingowe. Wydawnictwo Naukowe PWN, Warszawa 2007.

11. Bojar H. Wykorzystanie ankiety satysfakcji pacjentów z usług w zarządzaniu praktyką lekarza rodzinnego - narzędzie badawcze.StudiaEkonomiczne/UniwersytetEkonomicznyw Katowicach 2013; 168: 26-38.

12. Szpringer M, Chmielewski J, Kosecka J, et al. Poziom satysfakcji pacjenta jako jeden z aspektów jakości opieki medycznej. Med Ogólna Nauk Zdr 2015; 21: 132-137.

13. Kózka M, Gabryś T, Brzyski P, et al. Wybrane czynniki determinujące ocenę jakości opieki pielęgniarskiej w szpitalach pełniących stały dyżur. Wyniki projektu RN4CAST. Zdrowie Publiczne i Zarządzanie 2012; 10: 277-287.

14. Rysiak E, Donejko M, Galicka E, et al. Zarządzanie poprzez jakość w zakładach opieki zdrowotnej. Pol Prz Nauk Zdr 2014; 2: $146-148$. 